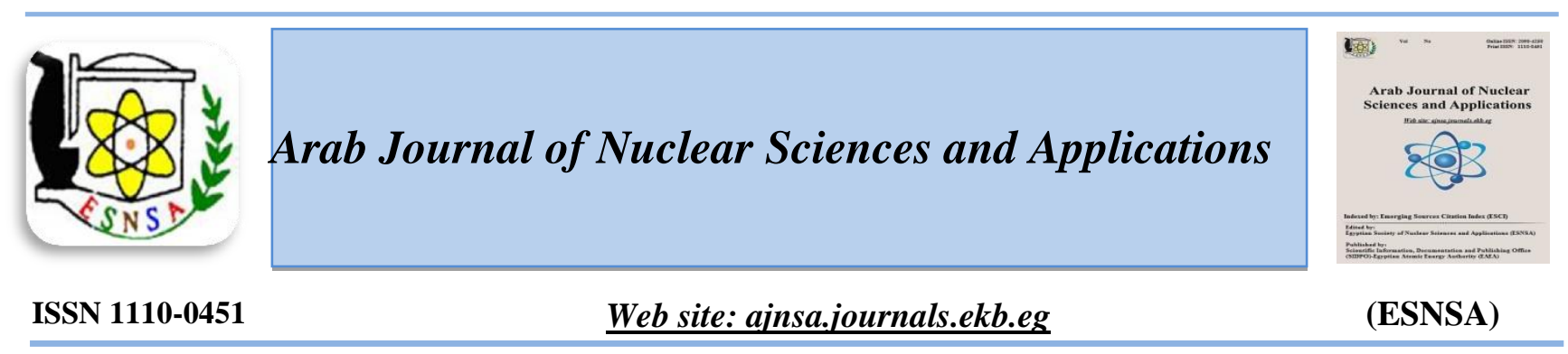

\title{
Effect of Irradiation and Edible Coating as Safe Environmental Treatments on The Quality and The Marketability of "Anna" Apples During Cold Storage
}

\author{
Naweto, M., Salem, A.E and Mostafa, M. \\ National Center for Radiation Research and Technology (NCRRT), Atomic Energy Authority, Cairo, Egypt
}

Received $3^{\text {th }}$ Oct. 2018 The present study was carried out during two successive seasons of 2014 and 2015 on "Anna"apples. The Accepted $11^{\text {th }}$ Dec. 2018 effect of gamma irradiationof 0.5 and $1.0 \mathrm{kGyin}$ addition to edible coating with paraffin oil and glycerol on the shelf-life and quality of apples during cold storage at $0^{\circ} \mathrm{C}, 90-95 \% \mathrm{RH}$ for 90 days was evaluated.Gamma irradiation of 0.5 and $1.0 \mathrm{kGycaused}$ a reduction in blue mold incidence $(\%)$ caused by Penicilliumexpansumin from $20.2 \%$ to $10.0 \%$ and $6.5 \%$ after 90 days cold storage however, in artificial inoculated fruits blue mold incidence reduced from $40 \%$ to $20.2 \%$ and $18.7 \%$ after 30 days.At 60 days, this level was reduced from $85 \%$ to $36.1 \%$ and $30 \%$. At the end of cold storage period,the blue mold was reduced from $100 \%$ to $55.7 \%$ and $42.1 \%$, respectively.The results indicated that irradiation and edible coating greatly affectedthe storage quality of apples. Edible coating paraffin oil or glycerol as well as irradiation of $1.0 \mathrm{kGy}$ were effective in increasing storability of apples during storage compared to $0.5 \mathrm{kGy}$ irradiation doses. These treatments decreased discarded and weight loss percentage and increased firmness, shelf life and calcium flesh of apples content. It could be noticed thatuntreated apples could be stored for 60 days where the treated ones by irradiation of $0.5 \mathrm{kGy}$ could be stored for 75 days.However edible coated apples or irradiationwith $1.0 \mathrm{kGy}$ could increase the storage period tobe 90 days.

Keywords: Irradiation, Edible coating paraffin oil or glycerol, Fungal mold, Anna apples, treatment, shelflife, Marketability

\section{Introduction}

Apples (Malusdomestica Bork) is considered one of the most important fruits in the world .Like most of the other perishable fruits, apples contain large amounts of water which causes a number of physiological and pathological disorders, and consequently causes a reduction in storage and shelf life. Many attempts were made for increasing the storage life in apple fruits. Postharvest pathogens cause major losses in apple production. More than 90 fungal species have been described as causative agents of apple decay during storage ( Pianzzola et al.,21). Blue mold caused by Penicilliumexpansum is the most important postharvest disease of apples(Gholamnejad et al.,11). This disease causes shortage of shelf-life andconsequentjy economic loss of apple. Cool storage is not enough to reduce the yield loss. Therefore, there is a need to search of alternative treatmentsto the commonly used fungicides in order to reduce the loss of yield(Mostafaviet $a l ., 17)$.

Gamma irradiation offers a promising method in increasing the storage life and shelf life, since it has a destructive effect on microorganisms and insect.The extension of fruit shelf life is an important goal to be attained. Many storage techniques have been developed to extend the marketing distances and holding periods for

Corresponding author: ehab_salem97@yahoo.com

DOI: 10.21608 /ajnsa.2018.5418.1123

(C) Scientific Information, Documentation and Publishing Office (SIDPO)-EAEA 
commodities after harvest. Different preservation methodologies have been studied.

One method of extending post-harvest shelf life is the use of the edible coatings that provide a semipermeable barrier against oxygen, carbon dioxide $\left(\mathrm{CO}_{2}\right)$, moisture and solute movement; thereby reducing respiration, water loss and oxidation reaction rates (Park,18).Proteins, lipids and polysaccharides are the main constituents of edible films and coatings. Among the studied proteins are wheat gluten, corn zein, soy protein, rice protein, egg albumin and milk proteins (PerezGago et al., 20); Falcão-Rodrigues et al.,10).Polysaccharide-based coatings, alginate, pectin's, cellulose and derivatives, starch and sucrose polyestershave been used to extend the shelf-life of fruits and vegetables (Rhim,23; RojasGrau et al.,24). Lipids also include waxes, acylglycerols and fatty acids have been used for extending the shelf-life of fruits and vegetables (Perez-Gago et al., 20); Falcão-Rodrigues et $a l ., 10)$.The objectives of this research is to evaluate the potential ofgamma irradiationdoses,edible coatings with paraffin oilandglycerol on keeping quality of "Anna" apples

\section{Materials and Methods}

The experiment was carried out during 2014 and 2015 seasons on mature "Anna" apples. Fruits were picked when the total red color reached about $50 \%$.Fruit firmness was about $12 \mathrm{lb} . / \mathrm{inch}^{2}$ and T.S.S \% was about $10.5 \%$ (ADS ,1). Undamaged mature Anna apple (MalusdomesticusBorkh) fruits of uniform size, shape, weight and color, free of physical damage as well as fungal infection were harvested in 2014 and 2015 seasons at Nubaria city, Egypt and transported to the National Center for Radiation Research and technology (NCRRT), Atomic Energy Authority Cairo, Egypt .The fruits were cleaned and divided into five groups ; each group was $36 \mathrm{Kg}$ of fresh and healthy fruits (5 treatments X 3 replicates X 2 boxes X6 Kg for each box $=180 \mathrm{Kg}$ for each). Five different experiments were carried out as follows:

Treatment 1: control(untreated).

Treatment 2: irradiation at $0.5 \mathrm{kGy}$.

Treatment 3: irradiation at $1.0 \mathrm{kGy}$.

Treatment 4: Fruits were coated with thin layer of paraffin oil( $99.0 \%)$.
Treatment 5: Fruits were coated with thin layer of Glycerol (99.0\%).

Each replicate consisted of two boxes, one box for studying physical properties and the other for determining chemical constituents.Control fruits werekept in carton boxes in each boxwithout any treatment, and all treatments were stored at $\left(0^{\circ} \mathrm{C}\right.$ and $90-95 \% \mathrm{RH})$.

\section{Irradiation treatments}

The irradiation of apples were carried out at room temperature using ${ }^{60} \mathrm{Co}$ source at the NCRRT. The irradiation facility used was an Egypt's Mega Gamma- 1, of the type J-6500 supplied by the Atomic Energy of Canada Limited. The applied doses were 0.0, 0.5, 1.0kGy for Anna fruits.The dose rate delivered during the experimental duration was $1 \mathrm{kGy} / \mathrm{hr}$., as monitored by radiochromic film (McLauchlin et al.,15).After irradiation treatment, the experimental materials(fruits) were transferred into a coldstorage room adjusted at $0^{\circ} \mathrm{C}, 90-95 \% \mathrm{RH}$.

\section{Edible coatings film}

Paraffin oil and glycerol (99.0\%) were of reagent grade (Gomhoria Co., Amireya-Cairo, Egypt).The fruits were immersed in paraffin oil or glycerol $(99.0 \%)$ film solutions for ( $2 \mathrm{~min}$.)then they were immediately towel- dried, placed in carton boxes and stored at $0{ }^{\circ} \mathrm{C}, 90-95 \% \mathrm{RH}$.

\section{Fungal species}

Penicilliumexpansum was isolated from apples showing blue mold.These fruits were kept in clean and sterile plastic bags at room temperature for isolation.Samples were sterilized with $1 \%$ sodium hypochlorite for $2 \mathrm{~min}$ then washed using sterilized distilled waterand dried using filter paper. Fungal isolation was carried out from the inner tissues neighboring the infected ones. Segments were separately transferred to Petri plates containing potato dextrose agar (PDA) media and incubated for 7 days at $27^{\circ} \mathrm{C}$ (Waller,27). The fungus was identified, according to the method reported by Raper and Thom (22). At Mycological Lab.2 (ML2),Faculty of Science, Zagazig University, Egypt. 
The following measurements were done

A- Fruit physical properities

1- Discarded fruits \%

The fruit did not show any sign of decay or visualdisorders during the storage time were counted and discarded every 15 days in apples, then the discarded \%apples was calculated according to(Kabeel,12).Any treatment was terminated in case of having $50 \%$ discarded fruits.

\section{2- Incidence percentage (\%) caused by $P$. expansum}

Apples were wounded on two opposite sides to a depth of $2 \mathrm{~mm}$ and were subsequently inoculated by immersion for 15 seconds in a conidial suspension $\left(1 \times 10^{5}\right.$ spores $\left./ \mathrm{ml}\right)$ of a virulent isolate of Pencilliumexpansum isolated from decayed apples and identified as previously mentioned. One hour after the inoculation, seven of the eight groups of inoculated apples (48 apples/group) were placed in three tray packed boxes with perforated polyethylene bags.The control group (No. 8) was inoculated and placed withouttreatment.All boxes were immediately stored at $0^{\circ} \mathrm{C}$, 9095\% RH,fordifferent storage periods.The results were calculated according to the method described by $($ Morcos, 16).

\section{3- Fruit weight loss(WL\%)}

The percentage weight loss of fruits (WL)was calculated at zero time of storage, then the initial weight of appleswas recorded and the WL was calculated by weighing the same fruits at the cold storage durations and every 15 days (Kabeel,12).

\section{4-Fruit firmness ( Lb./inch $\left.^{2}\right)$}

Fruit firmness was recorded before and after treatments and after storage as well as every 15 days for apples.Fleshfirmness was determinedaccording to (A.O.A.C,3).

\section{5- Fruit shelf- life (in days)}

A fruit sample from each replicate was taken out of the storage room and left at room temperature at $\left(28-26^{\circ} \mathrm{C}\right)$.When $50 \%$ of the fruits was scalded, the shelf- life was terminated and the number of days was calculated and considered as the shelflife.
B- Fruit chemical analysis

1- Total soluble solids (T.S.S.\%)

$20 \mathrm{~g}$ of fruit tissues were homogenized in a blender. The homogenized tissues were filtered using Whatman No.1 filter paper.The clear juice was decanted and used for T.S.S and titralable acidity analysis. Using hand refractometer, TSS \% was measured using drops of the above extracted juice according to(A.O.A.C,3). and the data was expressed as gm malice acid /100gm fresh.

\section{2- Titratable acidity (TA\%)}

The TA\% was detemined according to the official methods of Analysis (A.O.A.C.,2).

\section{3-Calcium fruit contents ( $\mathrm{Ca} \%$ )}

It was determined in fruits flesh sample of 0.2 oven-dried flesh was taken for Ca determination by ethylene diamine tetra acetate (Versenate method ) according to (Barrows and Simpson,5)and the data was expressed as mg / 100 gm dry weight .

\section{Experimental design and statistical analysis}

All treatments in this study were arranged in a complete randomized block deign. The data were subjected to analysis of variance using the general linear module procedure of (SAS,26), where appropriate treatment means were separated using Duncan's multiple range test(Duncan's,9) and all percentages were transferred to angles before statistical analysis.

\section{RESULTS AND DISCUSSION}

A-Effect of irradiation, coating with paraffin oil and glycerol on

\section{1-The physicalproperties of "Anna" apple fruits \\ Discarded fruits \%}

It was noticed that,the discarded fruits $\%$ increased with advancement in cold storage durations regardless of the used treatments.The primary mechanism of moisture loss from fresh fruits and vegetables is by vapor-phase diffusion driven by a gradient of water vapor pressure at different locations (Yaman and Bayoindirli,28).On the other hand, respiration causes a weight reduction because $\mathrm{CO}_{2}$ is lost from the fruit in each cycle (Bhowmik and Pan,7).However, the coating process caused a significant decrease in weight loss percentages (WLPs) compared tothe control sample. It is clear that, in all treatments,apples had 
a long storage life compared to the control group apples

Table (1)shows the changes of decay\% values of irradiated, coated and untreated apples during storage period. No decay signs were observed until 2 weeks after the beginning of the storage period.However, it could be seen that the fruit decay\% was increased by increasing the time in cold storage as well as control increased regardless of the type of treatments. Fruit decay\% increased from (2.40)after 30 days to (37.00)after 75 days of cold storage. However, all used treatments greatly decreased fruit decay \% comparedto the control with significant differences between them. The great effect was shown with coating paraffin oil and glycerol during all cold storage periods with no significant differences between coating paraffin

Table (1): Effect of irradiation,coating with paraffin oil and glycerol on Discarded fruits (\%) of "Anna" apple fruits during cold storage at $\left(0^{\circ} \mathrm{C}, 90-95 \% \mathrm{RH}\right)$, during 2014 and 2015 seasons

\begin{tabular}{|c|c|c|c|c|c|c|c|}
\hline \multirow[t]{2}{*}{ Treatments } & & \multicolumn{6}{|c|}{$\begin{array}{l}2014 \text { Seasons } \\
\text { Days in cold storage }\end{array}$} \\
\hline & & 15 & 30 & 45 & 60 & 75 & 90 \\
\hline \multirow{5}{*}{$\begin{array}{l}\text { Control } \\
\text { Irradiation } \\
\text { kGy } \\
\text { Irradiation } \\
\text { kGy } \\
\text { Paraffin oil } \\
\text { Glycerol }\end{array}$} & \multirow[b]{2}{*}{0.5} & $00.00 \mathrm{~A}$ & $2.40 \mathrm{~A}$ & $4.31 \mathrm{~A}$ & $17.74 \mathrm{~A}$ & $37.00 \mathrm{~A}$ & $*$ \\
\hline & & $00.00 \mathrm{~A}$ & $1.37 \mathrm{C}$ & $2.64 \mathrm{C}$ & $7.97 \mathrm{~B}$ & $20.01 \mathrm{C}$ & $41.12 \mathrm{~B}$ \\
\hline & \multirow[t]{3}{*}{1.0} & $00.00 \mathrm{~A}$ & $1.81 \mathrm{~B}$ & $3.01 \mathrm{BC}$ & $8.21 \mathrm{~B}$ & $14.09 \mathrm{D}$ & $25.35 \mathrm{C}$ \\
\hline & & $00.00 \mathrm{~A}$ & $0.82 \mathrm{D}$ & $1.33 \mathrm{E}$ & $6.00 \mathrm{~B}$ & $9.35 \mathrm{E}$ & $12.84 \mathrm{D}$ \\
\hline & & $00.00 \mathrm{~A}$ & $0.89 \mathrm{D}$ & $1.88 \mathrm{D}$ & $8.24 \mathrm{~B}$ & $9.99 \mathrm{E}$ & $13.00 \mathrm{D}$ \\
\hline & \multicolumn{7}{|c|}{2015 Seasons } \\
\hline \multirow{2}{*}{$\begin{array}{l}\text { Control } \\
\text { Irradiation } \\
\mathrm{kGy}\end{array}$} & \multirow[b]{2}{*}{0.5} & $00.00 \mathrm{~A}$ & $2.38 \mathrm{~A}$ & $4.18 \mathrm{~B}$ & $18.51 \mathrm{~B}$ & $47.81 \mathrm{~A}$ & $*$ \\
\hline & & $00.00 \mathrm{~A}$ & $1.65 \mathrm{~B}$ & $2.15 \mathrm{CD}$ & $11.01 \mathrm{C}$ & $45.68 \mathrm{~A}$ & $50.12 \mathrm{~A}$ \\
\hline $\begin{array}{l}\text { Irradiation } \\
\mathrm{kGy}\end{array}$ & 1.0 & $00.00 \mathrm{~A}$ & $1.55 \mathrm{~B}$ & $2.55 \mathrm{C}$ & $5.88 \mathrm{D}$ & $12.18 \mathrm{C}$ & $41.85 \mathrm{~A}$ \\
\hline Paraffin oil & & $00.00 \mathrm{~A}$ & $0.91 \mathrm{C}$ & $1.58 \mathrm{D}$ & $4.28 \mathrm{E}$ & $8.45 \mathrm{D}$ & $12.25 \mathrm{~B}$ \\
\hline Glycerol & & $00.00 \mathrm{~A}$ & $0.68 \mathrm{C}$ & $1.68 \mathrm{D}$ & $3.68 \mathrm{E}$ & $8.68 \mathrm{D}$ & $12.38 \mathrm{~B}$ \\
\hline
\end{tabular}

-Means having the same letter(s) in each column are statistically insignificant at $5 \%$ level.

-0.00 : Means no any discarded fruits at the beginning of the experiment.

-The experiment was terminated upon attaining $50 \%$ decay fruits.

Table (2):Effect of gamma irradiation on blue mold incidence in apple fruits caused bypenicilliumexpansum at different storage periods at $0^{\circ} \mathrm{C}, 90-95 \%$ RHin naturally and artificially infected fruits

\begin{tabular}{|c|c|c|c|c|c|c|c|c|}
\hline \multirow{4}{*}{$\begin{array}{l}\text { Gamma } \\
\text { Irradiation } \\
\text { kGy }\end{array}$} & \multicolumn{8}{|c|}{ Disease incidence $\%$} \\
\hline & \multicolumn{8}{|c|}{ Days in cold storage } \\
\hline & \multicolumn{4}{|c|}{ Naturally infected } & \multicolumn{4}{|c|}{ Artificial infected ( inoculated ) } \\
\hline & 0 & 30 & 60 & 90 & 0 & 30 & 60 & 90 \\
\hline 0.0 & 0.0 & 0.0 & 0.0 & 20.2 & 0.0 & 40 & 85 & 100 \\
\hline 0.5 & 0.0 & 0.0 & 0.0 & 10.0 & 0.0 & 20.2 & 36.1 & 55.7 \\
\hline 1.0 & 0.0 & 0.0 & 0.0 & 6.5 & 0.0 & 18.7 & 30 & 42.1 \\
\hline
\end{tabular}

Means with the same letter are not significantly 


\section{Blue mold incidence}

Table(2) shows that irradiation at doses of 0.5 and $1.0 \mathrm{kGy}$ reduced the blue mold incidence from $40 \%$ to $20.2 \%$ and $18.7 \%$,respectivelyafter 30 days but at 60 days reduced from $85 \%$ to $36.1 \%$ and $30 \%$, while at the end of the cold storage period,the blue mold was reduced from $100 \%$ to $55.7 \%$ to $42.1 \%$,respectively. The best result was shownat $1.0 \mathrm{kGy}$ at the end of cold storage periods.

\section{Weight loss (\%)}

Table (3) shows the changes of WLPs of irradiated , coatedwith paraffin oil or glycerol and untreated apples during storage. Generally, the WLP increased gradually during storage period.The primary mechanism of moisture loss from fresh fruits and vegetables is by vapor-phase diffusion driven by a gradient of water vapor pressure at different locations (Yaman and Bayoindirli, 28).On the other hand, the respiration causes a weight reduction because $\mathrm{CO}_{2}$ is lost from the fruit in each cycle (Bhowmilk, 7). However, WLPs of apples was gradually increased with advanced in storage periods where it increased from $2.38 \%$ (after 15 days) to $7.85 \%$ (after 60 days) in untreated fruits. Regarding the irradiation effect, it could be noticed that paraffin oil and glycerol were effective in reducing WLP of apples during storage.It is also clear that paraffin oil apples treated lost their weight after 75 days storage.It could be considered that paraffin oil treatment is suitable refrigeration treatment for apples due to its great effect on reducing fruit decay and WLP. Also, the coating process caused a decrease in WLPs compared to control sample. Control samples had a significantly higher WLP (7.85\%) for 60 days of the storage period, while apple samples coated with glycerol significantly have the lowest WLP -values $(4.95 \%)$. This reduction in weight loss was probably due to the effects of these coatings as a semi permeable barrier against oxygen, $\mathrm{CO}_{2}$, moisture and solute movement, thereby reducing respiration, water loss and oxidation reaction rates. Similar data were reported by (Bai et al. ,4), studying Gala apple, coated with $10 \%$ zein (natural corn protein). (Cong et al. ,8). noted that Chitosan and polyethylene wax (PE) coatings also provide good protection for Hami melon. The same trend of results was also found in the second seasons of study.

Table (3): Effect of irradiation, coating with paraffin oil and glycerol on weight loss(\%) of "Anna" apple fruits during cold storage at $\left(0^{\circ} \mathrm{C}, 90-95 \% \mathrm{RH}\right)$, during 2014 and 2015 seasons

\begin{tabular}{|c|c|c|c|c|c|c|c|}
\hline \multirow[t]{2}{*}{ Treatments } & & \multicolumn{6}{|c|}{2014 Seasons } \\
\hline & & 15 & 30 & 45 & 60 & 75 & 90 \\
\hline Control & & $2.38 \mathrm{~A}$ & $3.95 \mathrm{~A}$ & $5.15 \mathrm{~A}$ & $7.85 \leqslant \mathrm{~A}$ & * & * \\
\hline $\begin{array}{l}\text { Irradiation } \\
\text { k.Gy }\end{array}$ & 0.5 & $2.12 \mathrm{~B}$ & $3.28 \mathrm{~B}$ & $4.71 \mathrm{~B}$ & $6.05 \mathrm{AB}$ & $13.45 \mathrm{~A}$ & $*$ \\
\hline $\begin{array}{l}\text { Irradiation } \\
\text { k.Gy }\end{array}$ & 1.0 & $2.05 \mathrm{~B}$ & $2.67 \mathrm{C}$ & $4.42 \mathrm{~B}$ & $6.88 \mathrm{AB}$ & $12.25 \mathrm{~B}$ & $13.08 \mathrm{~A}$ \\
\hline Paraffin oil & & $1.68 \mathrm{D}$ & $2.08 \mathrm{D}$ & $3.51 \mathrm{C}$ & $6.48 \mathrm{AB}$ & $9.12 \mathrm{D}$ & $10.65 \mathrm{~B}$ \\
\hline Glycerol & & $1.75 \mathrm{~B}$ & $2.28 \mathrm{CD}$ & $3.65 \mathrm{C}$ & $4.95 \mathrm{~B}$ & $10.71 \mathrm{C}$ & $10.92 \mathrm{~B}$ \\
\hline \multicolumn{8}{|c|}{2015 Season } \\
\hline control & & $2.11 \mathrm{AB}$ & $4.08 \mathrm{AB}$ & $5.41 \mathrm{~B}$ & $7.85 \leqslant B$ & $*$ & $*$ \\
\hline $\begin{array}{l}\text { Irradiation } \\
\text { k.Gy }\end{array}$ & 0.5 & $2.28 \mathrm{~A}$ & $4.51 \mathrm{~A}$ & $6.38 \mathrm{~A}$ & $10.65 \mathrm{~A}$ & $13.45 \mathrm{~A}$ & $*$ \\
\hline $\begin{array}{l}\text { Irradiation } \\
\text { k.Gy }\end{array}$ & 1.0 & $1.78 \mathrm{~B}$ & $3.21 \mathrm{C}$ & $5.25 \mathrm{~B}$ & $7.68 \mathrm{~B}$ & $9.05 \mathrm{~B}$ & $13.08 \mathrm{~A}$ \\
\hline Paraffin oil & & $1.80 \mathrm{~B}$ & $2.28 \mathrm{D}$ & $3.58 \mathrm{C}$ & $5.85 \mathrm{C}$ & $8.12 \mathrm{~B}$ & $9.05 \mathrm{~B}$ \\
\hline Glycerol & & $1.75 \mathrm{~B}$ & $2.48 \mathrm{D}$ & $4.01 \mathrm{C}$ & $5.65 \mathrm{C}$ & $7.38 \mathrm{C}$ & $9.31 \mathrm{~B}$ \\
\hline
\end{tabular}

Legends as Table (1) 


\section{Firmness}

As shown in Table (4) the fruits firmness generally deceased with the increase in the storage periods regardless of the used treatment.No significant differences were noticed between different treatments in their effect on fruit firmness. This isbecause apples maturation is determined by $11.50 \mathrm{Lb} . /$ inch $^{2}$ fruit firmness.Concerning the effect of different treatments, it could be noticed that differences between treatments appeared after 30 days of storage. Irradiation at $1.0 \mathrm{kGy}$ and coating glycerol or paraffin oil treated fruit let to the higher fruit firmness values from 30 days till end of experiment compared with irradiation at 0.5 kGy.No significant different between coating glycerol or paraffin oil treated fruits in their firmness.At the end of storage, control samples clearly had the lowest firmness while apples coated with paraffin oil or glyceroland irradiationat 1.0 kGytreatment retained the highest firmness in both the first season and the second seasons.
Nevertheless, this edible coating still largely reduce firmness losses in comparson withthe untreated fruits.The retention of firmness can be attributed to the retarded degradation of insoluble protopectins to the more soluble pectic acid and pectin. During fruit ripening, depolymerization or shortening of chain length of pectin substances occurs with an increase in pectinesterase and polygalactronase activities(Yaman and Bayoindirli, 28). Low oxygen and high $\mathrm{CO}_{2}$ concentrations reduce the activities of these enzymes and allows retention of the firmness during storage (Salunkhe et al.,25).

Hence, the present results reasonably agree with the findings of Yaman and Bayoindirli (28) for cherries coated with Semperfresh ${ }^{\mathrm{TM}}$. Furthermore, Patricia et al., (19)reported that refrigerated strawberry coated with wheat gluten-based films had a better firmness retention than control fruit.

Table (4):Effect of irradiation,coating with paraffin oil and glycerol on firmness (Ib/inch ${ }^{2}$ )of "Anna" apple fruits during cold storage at $\left(0^{\circ} \mathrm{C}, 90-95 \% \mathrm{RH}\right)$, during 2014 and 2015 seasons

\begin{tabular}{|c|c|c|c|c|c|c|c|c|}
\hline \multirow[t]{2}{*}{ treatments } & & \multicolumn{6}{|c|}{2014 Seasons } & \\
\hline & & 0 & 15 & 30 & 45 & 60 & 75 & 90 \\
\hline control & & $12.62 \mathrm{~A}$ & $11.62 \mathrm{~A}$ & $9.52 \mathrm{~A}$ & $9.95 \mathrm{~A}$ & $8.08 \mathrm{BC}$ & $*$ & $*$ \\
\hline $\begin{array}{l}\text { Irradiation } \\
\mathrm{kGy}\end{array}$ & 0.5 & $12.15 \mathrm{~A}$ & $10.71 \mathrm{~A}$ & $8.92 \mathrm{~A}$ & $5.85 \mathrm{~A}$ & 7.78AB & $6.95 \mathrm{C}$ & $*$ \\
\hline $\begin{array}{l}\text { Irradiation } \\
\text { kGy }\end{array}$ & 1.0 & $12.35 \mathrm{~A}$ & $10.25 \mathrm{~A}$ & $9.98 \mathrm{~A}$ & $7.58 \mathrm{~A}$ & $8.25 \mathrm{~B}$ & $7.65 \mathrm{~B}$ & $5.72 \mathrm{~A}$ \\
\hline Paraffin oil & & $12.28 \mathrm{~A}$ & $10.42 \mathrm{~A}$ & $9.61 \mathrm{~A}$ & $9.02 \mathrm{~A}$ & $8.92 \mathrm{~A}$ & $8.52 \mathrm{~A}$ & $7.25 \mathrm{~A}$ \\
\hline Glycerol & & $12.12 \mathrm{~A}$ & $10.48 \mathrm{~A}$ & $9.95 \mathrm{~A}$ & $9.22 \mathrm{~A}$ & $8.82 \mathrm{AB}$ & 8.18AB & $6.62 \mathrm{~A}$ \\
\hline \multicolumn{9}{|c|}{2015 Season } \\
\hline control & & $11.51 \mathrm{~A}$ & $11.01 \mathrm{~A}$ & $9.15 \mathrm{BC}$ & $9.48 \mathrm{~A}$ & $8.21 \mathrm{BCD}$ & $*$ & $*$ \\
\hline $\begin{array}{l}\text { Irradiation } \\
\mathrm{kGy}\end{array}$ & 0.5 & $11.65 \mathrm{~A}$ & $10.48 \mathrm{~A}$ & $8.41 \mathrm{C}$ & $7.68 \mathrm{~A}$ & 7.61ED & $7.10 \mathrm{C}$ & $*$ \\
\hline $\begin{array}{l}\text { Irradiation } \\
\text { kGy }\end{array}$ & 1.0 & $11.88 \mathrm{~A}$ & $11.81 \mathrm{~A}$ & $9.35 \mathrm{ABC}$ & $9.15 \mathrm{~A}$ & 8.08CD & $7.28 \mathrm{C}$ & $5.72 \mathrm{~B}$ \\
\hline Paraffin oil & & $11.51 \mathrm{~A}$ & $11.81 \mathrm{~A}$ & $10.15 \mathrm{~A}$ & $9.51 \mathrm{~A}$ & $9.15 \mathrm{~A}$ & $8.05 \mathrm{~B}$ & $8.00 \mathrm{~A}$ \\
\hline Glycerol & & $11.85 \mathrm{~A}$ & $11.55 \mathrm{~A}$ & $10.25 \mathrm{~A}$ & $9.78 \mathrm{~A}$ & $8.81 \mathrm{AB}$ & $8.35 \mathrm{~A}$ & $8.04 \mathrm{~A}$ \\
\hline
\end{tabular}

Legends as Table (1)

\section{Marketability shelf-life}

Table (5) shows the effect of different supplementary refrigeration treatmentson the marketabilityshelf-life of apples, which indicates that it was gradually decreased with increasing days in storage regardless of the used treatments. The great effect on shelf life was observed with the fruit treated withglycerolor paraffin oil followed irradiation at $1.0 \mathrm{kGytreatment}$ in both seasons. However, irradiated fruit especially at $0.5 \mathrm{kGyhad}$ a lower shelf-life than that irradiated at $1.0 \mathrm{kGyafter}$ 2 months of storage, whereas it decreases after 75 days of storage paraffin oil treated. In this concern (Kovacs et al.,13), stated that other negative 
effects resulting from irradiation with $1.0 \mathrm{kGy}$, besides fruit softening, are dissolution of middle lamella, wrinkling of cell membrane and retention of starch by plastid of the skin.Differences between paraffin oil or glycerol were insignificant, so, paraffin oil could be recommended as supplementary refrigeration treatment for apples.The above mentioned results are in agreement with those reported by(Bhadra and Sen ,6).

\section{2- Chemical analysisof "Anna" apple fruits}

Table (6): Effect of irradiation,coating with paraffin oil and glycerol on Total Soluble Solids(TSS) of "Anna" apple fruits during cold storage at $\left(0^{\circ} \mathrm{C}, 90-95 \% \mathrm{RH}\right)$,during 2014 and 2015 seasons

\section{Total soluble solids (TSS \%)}

Table(6) shows the changes of TSS values of irradiation doses, edible coating treatments and untreated apples during storage period. Control samples, without treatmentsand edible coating treatments showed an increase in the TSS after 45 days of storage and decreased after 60 days. The highest level of TSS value was observed after 75 days of storage at coating paraffin oil treatment and the lowest level of TSS was at $0.5 \mathrm{kGy}$. The same trend of results was also found in the second seasons of study. Similar effects were reported for strawberry coated with wheat gluten-based film by(Patricia et al.,19).

\section{Titratable acidity}

Table(7) shows that Titratable Acidity (TA)values were gradually and significantly decreased with increasing the storage period.Control samples had the lowest level of TA and the highest level of TA was paraffin oil after 60 days in storage. At the end of storage period TA of apples coated with glycerol,paraffin oil and irradiation at $1.0 \mathrm{kGy}$ treated were approximately $0.42,0.41$ and 0.40 times higher than TA of control and irradiation at $0.5 \mathrm{kGy}$ treatment, respectively. Since, organic acids such as malic or citric acid are primary substrates for respiration, a reduction in acidity and, hence, an increase in $\mathrm{pH}$ are expected in highly respiring fruits. Coatings reduce respiration rates and delay the utilization of organic acids (Yaman and Bayoindirli, 28).Also,Patricia et al., (19), indicated that coating with PVC pack were effective in the retention of TA of strawberry fruit during the storage time.

Table (5):Effect of irradiation,coating with paraffin oil and glycerol on marketability shelf-life(in days)of "Anna" apple fruits during cold storage at $\left(0^{\circ} \mathrm{C}, 90-95 \%\right.$ RH),during 2014 and 2015 seasons

\section{Seasons}

\begin{tabular}{|c|c|c|c|c|c|c|c|c|c|}
\hline \multirow[t]{2}{*}{ treatments } & & \multicolumn{8}{|c|}{ Days in cold storage } \\
\hline & & 0 & 15 & 30 & 45 & 60 & 75 & & 90 \\
\hline control & & $9.95 \mathrm{~A}$ & $9.28 \mathrm{BC}$ & $8.95 \mathrm{BC}$ & $6.28 \mathrm{C}$ & $3.95 \mathrm{~B}$ & $*$ & & $*$ \\
\hline $\begin{array}{l}\text { Irradiation } \\
\mathrm{kGy}\end{array}$ & 0.5 & $10.28 \mathrm{~A}$ & $8.95 \mathrm{C}$ & $6.62 \mathrm{C}$ & $4.28 \mathrm{D}$ & $3.28 \mathrm{C}$ & $3.28 \mathrm{~B}$ & & $*$ \\
\hline $\begin{array}{l}\text { Irradiation } \\
\mathrm{kGy}\end{array}$ & 1.0 & $9.95 \mathrm{~A}$ & $10.28 \mathrm{AB}$ & $8.61 \mathrm{~B}$ & 7.62BC & $5.95 \mathrm{AB}$ & $4.95 \mathrm{~A}$ & & $2.28 \mathrm{~A}$ \\
\hline Paraffin oil & & $10.61 \mathrm{~A}$ & $10.28 \mathrm{AB}$ & $9.95 \mathrm{~A}$ & $8.95 \mathrm{~A}$ & $6.62 \mathrm{~A}$ & $5.28 \mathrm{~A}$ & & $2.61 \mathrm{~A}$ \\
\hline Glycerol & & $10.28 \mathrm{~A}$ & $10.62 \mathrm{~A}$ & $9.61 \mathrm{AB}$ & $8.62 \mathrm{AB}$ & $6.62 \mathrm{~A}$ & $5.28 \mathrm{~A}$ & & $2.95 \mathrm{~A}$ \\
\hline \multicolumn{10}{|c|}{2015 Season } \\
\hline control & & $9.95 \mathrm{C}$ & $9.28 \mathrm{CD}$ & $7.95 \mathrm{BC}$ & $7.95 \mathrm{BC}$ & $6.28 \mathrm{BC}$ & $*$ & & $*$ \\
\hline $\begin{array}{l}\text { Irradiation } \\
\mathrm{kGy}\end{array}$ & 0.5 & $10.95 \mathrm{AB}$ & $8.61 \mathrm{D}$ & $5.61 \mathrm{D}$ & $5.61 \mathrm{D}$ & $4.61 \mathrm{D}$ & 3.23 & B & * \\
\hline $\begin{array}{l}\text { Irradiation } \\
\mathrm{kGy}\end{array}$ & 1.0 & $10.61 \mathrm{AB}$ & $9.95 \mathrm{BC}$ & $8.61 \mathrm{~B}$ & $8.61 \mathrm{~B}$ & $7.28 \mathrm{~B}$ & 6.95 & A & $5.80 \mathrm{AB}$ \\
\hline Paraffin oil & & $10.61 \mathrm{AB}$ & $10.1 \mathrm{AB}$ & $10.28 \mathrm{~A}$ & $10.28 \mathrm{~A}$ & $9.28 \mathrm{~A}$ & 7.28 & A & $5.95 \mathrm{AB}$ \\
\hline Glycerol & & $11.28 \mathrm{~A}$ & $10.95 \mathrm{~A}$ & $9.95 \mathrm{~A}$ & $9.95 \mathrm{~A}$ & $9.28 \quad \mathrm{~A}$ & 7.28 & A & $6.25 \mathrm{~A}$ \\
\hline
\end{tabular}

Legends as Table (1) 
Table (6):Effect of irradiation,coating with paraffin oil and glycerol on Total Soluble Solids(TSS) of "Anna" apple fruits during cold storage at $\left(0^{\circ} \mathrm{C}, 90-95 \% \mathrm{RH}\right)$,during 2014 and 2015 seasons 2014 Season

\begin{tabular}{|c|c|c|c|c|c|c|c|c|}
\hline \multirow{2}{*}{ treatments } & & \multicolumn{7}{|c|}{ Days in cold storage } \\
\hline & & 0 & 15 & 30 & 45 & 60 & 75 & 90 \\
\hline control & & $11.08 \mathrm{~A}$ & $11.88 \mathrm{~A}$ & $12.15 \mathrm{~A}$ & $12.75 \mathrm{~A}$ & $11.22 \mathrm{~A}$ & $*$ & $*$ \\
\hline $\begin{array}{l}\text { Irradiation } \\
\mathrm{kGy}\end{array}$ & 0.5 & $11.38 \mathrm{~A}$ & $11.55 \mathrm{~A}$ & $12.82 \mathrm{~A}$ & $12.82 \mathrm{~A}$ & $11.75 \mathrm{~A}$ & $10.59 \mathrm{~A}$ & $*$ \\
\hline $\begin{array}{l}\text { Irradiation } \\
1.0 \mathrm{k} . G y\end{array}$ & & $10.95 \mathrm{~A}$ & $11.48 \mathrm{~A}$ & $12.65 \mathrm{~A}$ & $12.61 \mathrm{~A}$ & $11.62 \mathrm{~A}$ & $10.62 \mathrm{~A}$ & $10.42 \mathrm{~A}$ \\
\hline Paraffin oil & & $10.82 \mathrm{~A}$ & $11.55 \mathrm{~A}$ & $12.48 \mathrm{~A}$ & $12.75 \mathrm{~A}$ & $11.28 \mathrm{~A}$ & $10.81 \mathrm{~A}$ & $10.55 \mathrm{~A}$ \\
\hline Glycerol & & $10.95 \mathrm{~A}$ & $11.88 \mathrm{~A}$ & $12.55 \mathrm{~A}$ & $12.22 \mathrm{~A}$ & $11.28 \mathrm{~A}$ & $10.95 \mathrm{~A}$ & $10.62 \mathrm{~A}$ \\
\hline \multicolumn{9}{|c|}{2015 Season } \\
\hline control & & $12.81 \mathrm{~A}$ & $13.38 \mathrm{AB}$ & $13.38 \mathrm{AB}$ & $13.85 \mathrm{~A}$ & $13.91 \mathrm{~A}$ & $*$ & $*$ \\
\hline $\begin{array}{l}\text { Irradiation } \\
\text { kGy }\end{array}$ & 0.5 & $12.31 \mathrm{~A}$ & $13.55 \mathrm{AB}$ & $13.81 \mathrm{~A}$ & $13.75 \mathrm{~A}$ & $13.45 \mathrm{~A}$ & $12.00 \mathrm{AB}$ & $*$ \\
\hline $\begin{array}{l}\text { Irradiation } \\
\text { kGy }\end{array}$ & 1.0 & $12.41 \mathrm{~A}$ & $12.68 \mathrm{AB}$ & $14.15 \mathrm{~A}$ & $13.55 \mathrm{~A}$ & $13.61 \mathrm{~A}$ & $12.25 \mathrm{AB}$ & $12.25 \mathrm{~A}$ \\
\hline Paraffin oil & & $12.38 \mathrm{~A}$ & $14.25 \mathrm{~A}$ & $13.15 \mathrm{AB}$ & $13.21 \mathrm{~A}$ & $13.38 \mathrm{~A}$ & $12.81 \mathrm{~A}$ & $12.35 \mathrm{~A}$ \\
\hline Glycerol & & $12.75 \mathrm{~A}$ & $13.11 \mathrm{AB}$ & $14.18 \mathrm{~A}$ & $13.85 \mathrm{~A}$ & $13.78 \mathrm{~A}$ & $12.95 \mathrm{~A}$ & $12.41 \mathrm{~A}$ \\
\hline
\end{tabular}

Legends as Table 1

Table (7):Effect of irradiation,coating with paraffin oil and glycerol on Titratable acidity(gm malice acid /100gm fresh) of "Anna" apple fruits during cold storage $\operatorname{at}\left(0^{\circ} \mathrm{C}, 90-95 \% \mathrm{RH}\right)$,during 2014 and 2015 seasons

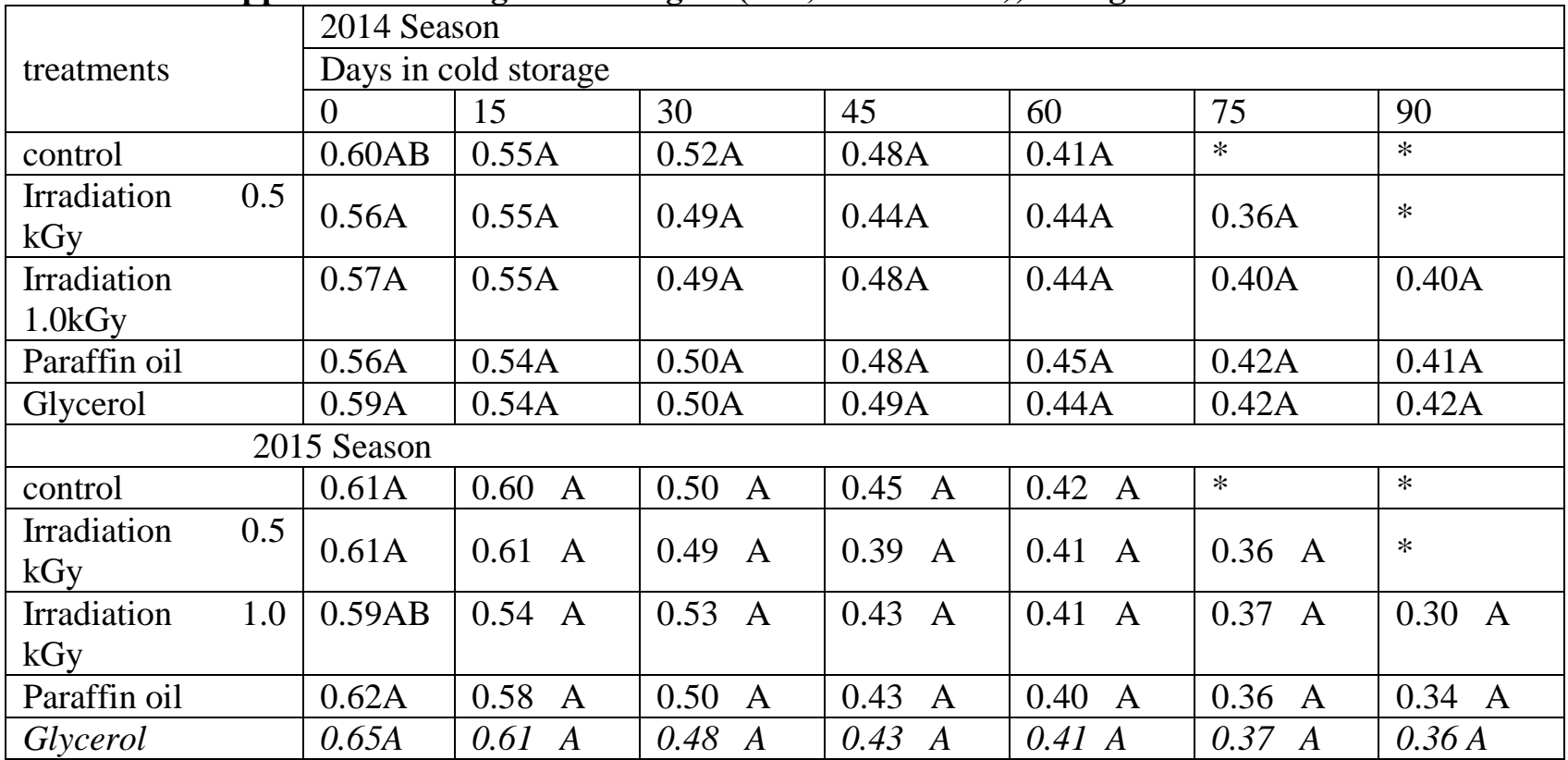

\section{Legends as Table 1}

\section{Calcium flesh content}

Table(8)showsthat the Ca flesh content decreases with increasing storage duration in all groupsat 30 days of storage and the treated fruits with paraffin oil or glycerol showed the highest values of $\mathrm{Ca}$ flesh content compared tothe control or irradiation treatments up to $1.0 \mathrm{kGy}$. The great effect of edible coatings with paraffin oil and glycerol on reducing the rate of $\mathrm{Ca}$ flesh content losses continued with all cold storage periods. In this concern (Lurie et al.,14).confermid that there was less wax on the surface of the heated fruits than the unheated fruits. It is suggested that during heat treatment the wax softens and fills in the cracks while water loss pull 
Table (8):Effect of irradiation,coating with paraffin oil and glycerol on Calcium flesh content $(\mathrm{mg} / 100 \mathrm{~g}$ dry weight) of “Anna" apple fruits during cold storage at $\left(0^{\circ} \mathrm{C}, 90-95 \% \mathrm{RH}\right)$, during 2014 and 2015 seasons

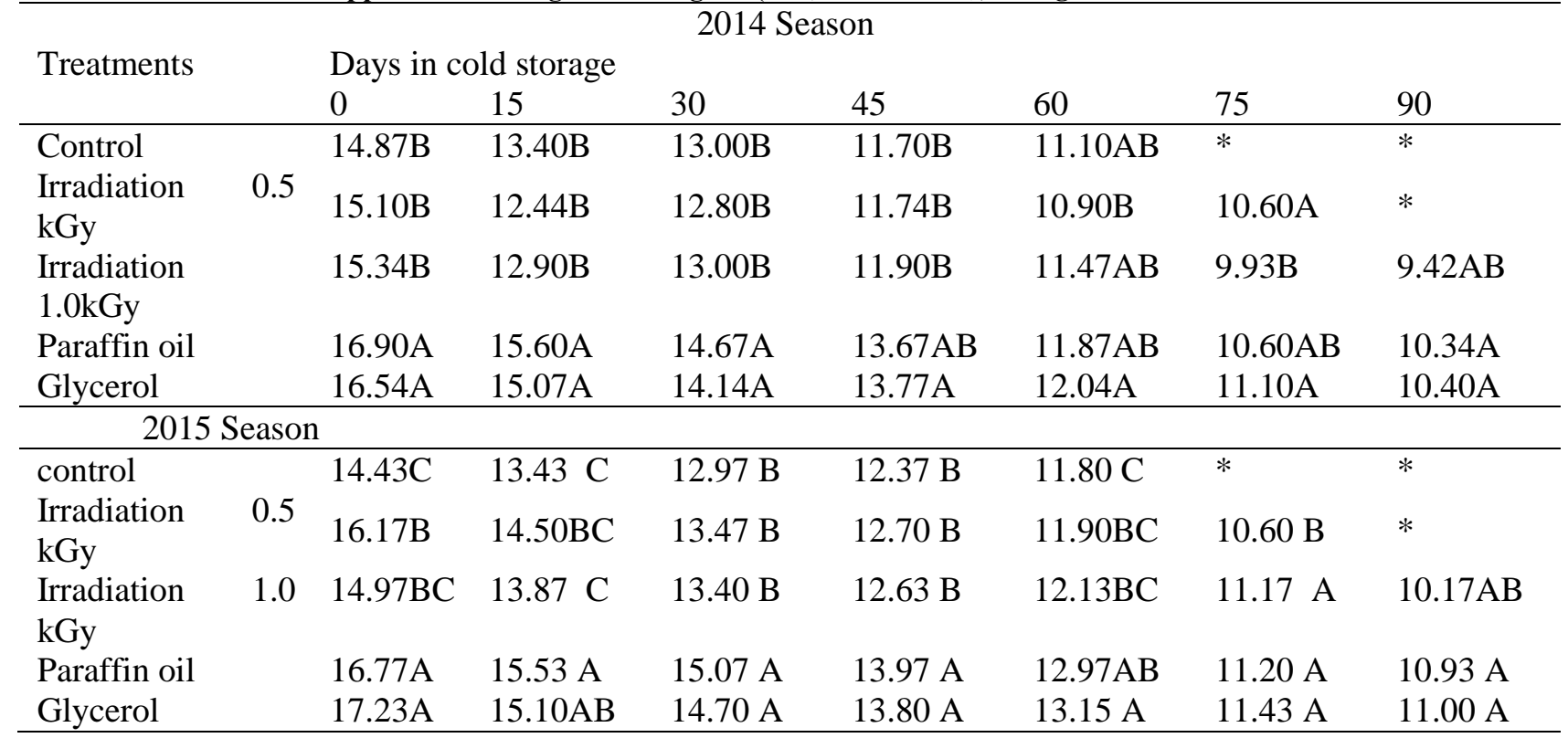

\section{Legends as Table 1}

the fruit calcium towards the fruit surface. This continuos wax layer on heated fruits decreases the ability of external calcium to move into the fruit.After 60 days of storage $\mathrm{Ca}$ flesh content of apples was ranged from 11.10 for control to $12.04,11.87,11.47$ and $10.90(\mathrm{mg} / 100 \mathrm{~g}$ dry weight $)$ for glycerol, paraffin oil, Iirradiation at $1.0 \mathrm{k} . \mathrm{Gy}$ and $0.5 \mathrm{kGy}$, respectively. These values could be an indicator for determining the storage ability of apples and reduction of $\mathrm{Ca}$ flesh content than this value caused many disorders and shortened shelf life of the fruits .

\section{Conclusion}

The results indicated that irradiation and edible coating as supplementary refrigeration treatments greatly affected the keeping quality of apples. Edible coating paraffin oil or glycerol and irradiation at $1.0 \mathrm{kGy}$ were effective than $0.5 \mathrm{kGy}$ in increasing storability of apples during cold storage at $0^{\circ} \mathrm{C}, 90-95 \% \mathrm{RH}$.These treatments decreased discarded fruits and weight loss $\%$ and increased fruit firmness, shelf life and fruit calcium flesh content compared with $0.5 \mathrm{kGy}$ or control fruits. A slight effect was noticed on chemical constituents of the fruits during cold storage duration. It could be noticed that untreated apples could be stored for 60 days where the treated fruits are by the irradiation at $0.5 \mathrm{kGy}$ stored for 75 days but edible coated apples with (paraffin oil or glycerol) or irradiation at $1.0 \mathrm{kGy}$ could be stored for 90 days.

\section{References}

1-Agricultural Development Systems Project ADS, 1982.Horticulture Subproject Deciduous Trees Activity .Improvement Deciduous Fruit Cultivars and stookin Egypt . Annual Scientific Report . 1983 1984.

2-A. O. A.C. 1980.Association of Official AnalyticalChemists Methods of Analysis Washington D.C.,USA.

3-A. O. A.C.1990.Official methods ofAnalysis.TheAssociation of Official Analytical Chemist.ArlingtonWest

Virginia,USA, $15^{\text {th }}$ Ed.WashingtonD.C.

4-Bai, J. V. Alleyne, R. D.Hagenmaier,J. P.Mattheis and Baldwin, E. A .2003.Formulation of zeincoatings for apples (Malusdomesticaborkh). Postharvest Biology and Technology28: 259-268.

5-Barrows, L. H. and Simpson, E. C.1962.EDTA method for the direct routine determination of calcium and magnesium in soil and plant tissues Soil Science Society of America, Proceedings 26: 443 .

6-Bhadra, S. and Sen,S. K.1999.Post Harvest storage of Custard apple (Annonasqyamosa L. ) fruit var. Local Green under various chemical and wrapping treatments. Environment and Ecology 17 (3) : $710-$ 713 . ( c.f.Hort. Abst. 70, 2434).

7-Bhowmik, S. R. and Pan, J.C.1992.Shelf life of mature green tomatoes stored in controlled atmosphere and high humidityJournal of Food Sciences57: 948-953. 
8-Cong, F. Zhang, Y. and Dong,W.2007.Use of surface coatings with natamycin to improve the storability of Hami melon at ambient temperaturePostharvestBiology and Technology46: 71-75.

9-Duncan, D. B.1955.Multiple F Test Biometrics 11:1 -42 .

10-Falcão-Rodrigues, M. M .Moldão-Martins, M. andBeirão-da-Costa,M.L.2007.DSC as a tool to assess physiological evolution of apples preserved by ediblescoatingsFood Chemistry 102: 475-480.

11-Gholamnejad, J.Etebarian, H.R .Roustaee ,A.andNavazSahebani,N. 2009.Biological control of apples blue mold by isolates of Saccharomyces cerevisiaeJournal ofPlant Protection Research.49 (No. 3), $270-275$.

12-Kabeel, N. M.1990.Physiological studies on increasing the keeping quality ofBaladyEgyption lime fruits (Benzaer)Ph.D.thesis, Faculty of Agriculture, CairoUniversity.

13-Kovacs, E.Keresztes, A. and Kovacs, J.1988.The effect of gamma irradiation and calciumtreatment on the ultra structure of apples and pearsFoodMicrostructure 7: 1 - 14 .

14-Lurie,S.Fallik, E. and Klein, J. D.1996 . The effect of heat treatment on apple epicuticular wax and calcium uptake Postharvest - Biology and Tecnology8 (4) : $271-277$.

15-McLauchlin,W.L.Chen, W. Jia,H. and Humphreys, J.C.1985.Response of radichromicfilmdosimeter to gamma rays in different atmospheres Radiation Physics and Chemistry 25:793- 797.

16-Morcos Jeanette, F. 1984.Studies on rots of pome fruits in A R E M. Sc.Thesis,Facultyof Agriculture, Cairo University133 p.

17-Mostafavi, H. A.Mirmajlessi, S. M .Seyed, M. M.Fathollahi, H. and Askari, H.2012.Gamma radiation effects on physico-chemical parameters of apple fruit duringcommercial post-harvest preservationRadiation Physics and Chemistry81, 666-671.

18-Park, H.J. 1999.Development of advanced edible coatings for fruits Trends in Food Sciences\&Technology10: 254-260.

19-Patricia, S.Tanada-Palmu and Carlos, R. F. Grosso . 2005.Effect of edible wheat gluten-based films and coatings on refrigerated strawberry (Fragariaananassa) quality.
20-Perez-Gago, M. B.Serra, M. and Del Rio, M .A.2005.Color change of fresh-cut apples coated with whey protein concentrate-based edible coatings. Postharvest Biology andTechnology39: 84-92.

21-Pianzzola,M.J.M.Moscatelli and Vero,S.2004. Characterization of Penicillium Isolates associated with blue mold on apple in UruguayPlant Disease Vol. 88 (No. 1), 23 - 28.

22-Raper, K. B and Thom, C. 1968. A Manual of the PenicilliaHeftner Publishing Company, New York and London.

23-Rhim, J.W.2004. Physical and mechanical properties of water resistant sodium alginate filmsLebensmittelWissenschaft und-Technologie37: 323-330.

24-Rojas-Grau,M.A.Tapia,M.S.Rodri-guezb,F.J .Carmonac, A. J and Martin-Belloso,O. 2007. Alginate and gellan-based edible coatings as carriers ofantibrowning agents applied on fresh-cut Fuji applesFood Hydrocolloids 21:118-127.

25-Salunkhe D K,Boun H R and Reddy N R.1991. Storage Processing and Nutritional Quality of Fruits and Vegetables Chemical Rubber Company Press Inc Boston Vol. 1

26-SAS institute1985.SAS user's guide statistics for personal computers version $5^{\text {th }}$ ed. SAS Inst Cary NCO .

27-Waller J M. 1981. Rev. of Plant Pathology60: 153160

28-Yaman O and BayoindirliL.2002.Effects of an edible coating and cold storage on shelf-life and quality of cherriesLebensmittel-Wissenschaft und Technologie35: 146-150. 